\title{
A evidência científica a serviço da gestão em saúde
}

É esse o tema que guia a comissão científica do $39^{\circ}$ Congresso Brasileiro de Patologia Clínica/Medicina Laboratorial, que se realizará de 19 a 22 de outubro de 2005, em São Paulo. Como sempre, é preciso que o congresso abranja todas as áreas do laboratório clínico, e desta vez não será diferente. Mas o tema com certeza nos inspira reflexões únicas.

A medicina diagnóstica é uma área onde, cada vez mais e com maior velocidade, são incorporadas novas tecnologias, as quais passam a ser disponibilizadas a médicos e pacientes em prazo recorde entre pesquisa, desenvolvimento e uso. Isso faz com que tenhamos recursos cada vez mais amplos, sendo que alguns estudiosos afirmam ser a medicina complementar responsável por até $70 \%$ das evidências usadas hoje pelos médicos para suas conclusões e condutas. Contudo, também faz com que o tempo necessário para a realização de estudos que forneçam as evidências para a utilidade de novos testes seja muito pequeno, muitas vezes insuficiente para uma análise prospectiva e abrangente.

Por outro lado, há um alegado aumento do custo gerado pelo uso das novas tecnologias, do qual se ressentem, principalmente, os financiadores dos serviços de saúde, e com o qual aparentemente se regozija a indústria diagnóstica. Como acima, contudo, não se consegue avaliar os benefícios, diretos e indiretos, gerados para a pessoa e para a sociedade em decorrência do uso da tecnologia para o prolongamento da vida humana com qualidade. Talvez nem haja parâmetros capazes de medir esse impacto de forma inquestionável.

Esse delicado impasse nos leva à conclusão, aliás bastante óbvia, de que o progresso científico e tecnológico é uma decorrência da capacidade humana de atuar sobre o meio e não pode nem deve ser bloqueado. Mas é urgente que o mesmo intelecto e a mesma competência sejam colocados a serviço da criação de um novo modelo de medicina diagnóstica. Devemos criar um novo paradigma de atuação que privilegie a indicação correta, o teste correto realizado na seqüência correta com a qualidade analítica adequada. Esse modelo teria que ser, forçosamente, baseado em evidências e teria que incluir o patologista clínico de forma orgânica em todo o processo de utilização dos recursos laboratoriais. Como remunerar com justiça os serviços laboratoriais, em um modelo que não se baseie na quantidade de exames solicitados, e sim na racional utilização dos recursos disponíveis: esse é o nosso desafio.

Deixo vocês com a Rainha Vermelha: "Você pode chamar isso de disparate, se quiser. Mas eu já ouvi disparates perto dos quais o que eu acabo de dizer parece tão sensato quanto um dicionário" (Carrol, L. Através do Espelho). 